\section{ВИЗНАЧЕННЯ ТЕОРЕТИКО- МЕТОДОЛОГІЧНИХ КОНЦЕПТІВ УПРАВЛІННЯ ЕФЕКТИВНИМ РОЗВИТКОМ РИНКУ \\ ЕКОЛОГІЧНО ЧИСТИХ ТОВАРІВ УКРАЇНИ}

\author{
СИВОЛАП Л. А., \\ доктор економічних наук, доцент, \\ СОЛОХА Д. В., \\ доктор економічних наук, \\ професор, \\ ЧЕЛПАН В. М., \\ магістрант гр. УПЕП-20 м/3, \\ Донецький державний \\ університет управління
}

\section{DEFINITION OF THEORETICAL AND METHODOLOGICAL CONCEPTS OF MANAGEMENT OF EFFECTIVE MARKET DEVELOPMENT ENVIRONMENTALLY CLEAN GOODS OF UKRAINE}

B роботі досліджено теоретико-методологічні концепти забезпечення формування й розвитку ринку екологічно чистих товарів в Україні, як вагомої складової національного ринку в изілому. Ринок екологічно чистих товарів розглядається як динамічна модель, щчо знаходиться під постійним впливом факторів зовнішнього середовища, визначено основні фактори впливу на ефективність довгострокового розвитку ринку, встановлено їх взаємозв'язок, взаємовпливовість й взаємозалежність.

Ключові слова: розвиток, ефективність, управління, ринок, екологічно чистий товар, начіональне господарство.

В работе исследованы теоретико-методологические концепты обеспечения формирования и развития рынка экологически чистых товаров в Украине как весомой составляющей начионального рынка в целом. Рынок экологически чистых товаров рассматривается как динамическая модель, находится под постоянным воздействием факторов внешней среды, определены основные факторы влияния на эффрективность долгосрочного развития рынка, установлено их взаимосвязь, взаимовоздействие и взаимозависимость.

Ключевые слова: развитие, эффективность, управление, рынок, экологически чистый товар, национальное хозяйство.

The article researches the theoretical and methodological concepts of ensuring the formation and development of the market of environmentally friendly goods in Ukraine as a significant component of the national market as a whole. The market for environmentally friendly goods is considered as a dynamic model, is under the constant influence of environmental factors, the 
main factors of influence on the efficiency of long-term market development are determined, their interconnection, interaction and interdependence are established.

Key words: development, efficiency, management, market, environmentally friendly goods, national economy.

Постановка проблеми. Інтеграційні процеси, що відбуваються практично в усіх сферах національного господарства України, спонукають суб'єкти господарювання всіх рівнів дослідження економічних систем адаптуватися до вимог й стандартів світового ринку, що в свою чергу дасть змогу з одного боку закріпитися на ньому, з іншого - розширити існуючий та оволодіти новими сегментами світового ринкового простору.

Відповідно до реалізації засад Концепції сталого розвитку [5], вельми важливим за сучасних умов ведення бізнесу $є$ екологізація виробництва задля випуску максимальної кількості екологічно чистих товарів (ЕЧТ), з дотриманням екологічної чистоти на всіх етапах виробництва - віл видобутку сировини до реалізації готової продукції.

Отже, обрана тема даної наукової статті є досить актуальною, а питання, що в ній розглядаються своєчасні й потребують розвинення і поглиблення теоретико-методологічних концептів формування ринку ЕЧТ та його ефективного розвитку в довгостроковій перспективі.

Аналіз останніх досліджень $і$ публікацій. Проблематиці функціонування національного господарства, ефективності управління вітчизняним ринком в цілому, та його екологічній складовий зокрема, присвячені наукові роботи сучасних науковців, зокрема, [1-4; 6-9], й інших.

Однак, динамічність змін ринкового середовища як національного, так й світового рівня, потребують подальшого наукового пошуку, дослідження існуючого досвіду управління ефективним розвитком ринку ЕЧТ, тощо.

Дослідження, основні результати якого представлені в даній статті, $\epsilon$ складовою частиною науково-дослідної роботи Донецького державного університету управління МОН України за темою «Удосконалення механізмів управління формуванням та впровадженням екологічної політики в сучасних умовах» (номер держреєстрації 0118U003105).

Mета статmі полягає у встановленні й досліджені основних теоретикометодологічних концептів забезпечення ефективного розвитку вітчизняного ринку екологічно чистих товарів в стратегічній перспективі.

Виклад основного матеріалу дослідження. Забезпечення ефективності процесу управління розвитком ринкового середовища в Україні, безпосередньо пов'язано 3 формуванням економічного механізму стратегічного управління, спрямованого на інтеграцію всіх параметрів росту, цілеспрямованим впливом на різнорівневі й різноспрямовані фактори розвитку, створення зовнішніх i внутрішніх умов, що дозволяють ініціювати довгостроковий і сталий розвиток, проводити моніторинг його можливих напрямків і наслідків й відповідно до Концепції сталого розвитку [5] розвивати екологічну складову такого розвитку.

Глобальним критерієм ефективності управління розвитком ринкового середовища в цілому й ринку ЕЧТ, як його вагомої складової є стійкий розвиток 
національної економіки в стратегічній перспективі при всій повноті виконання національною економікою своїх функцій [8].

3 глобального критерію ефективності управління розвитком вітчизняного ринку, виокремимо локальні критерії. Вони повинні враховувати специфіку відповідного рівня управління, на якому виміряється ефективність, і бути адекватними головному критерію.

Усі основні елементи, що формують ефективність управління ринковим розвитком, можна представити у вигляді схеми (рис. 1), на якій у якості основних складових нами виділені:

- економічні ефекти (обсяг випуску продукції, обсяг продажів, прибуток, операційний прибуток, прибуток після сплати податків, тобто всі ефекти спрямовані на отримання прибутку і т.п.);

- соціальні ефекти (рівень зарплати, рівень доходів, якість життя, охорона праці і т.п.);

- геополітичні ефекти (положення щодо світових ринків, імідж, ступень впливу тощо);

- екологічні ефекти (стан навколишнього середовища, норми забруднення, очищення).

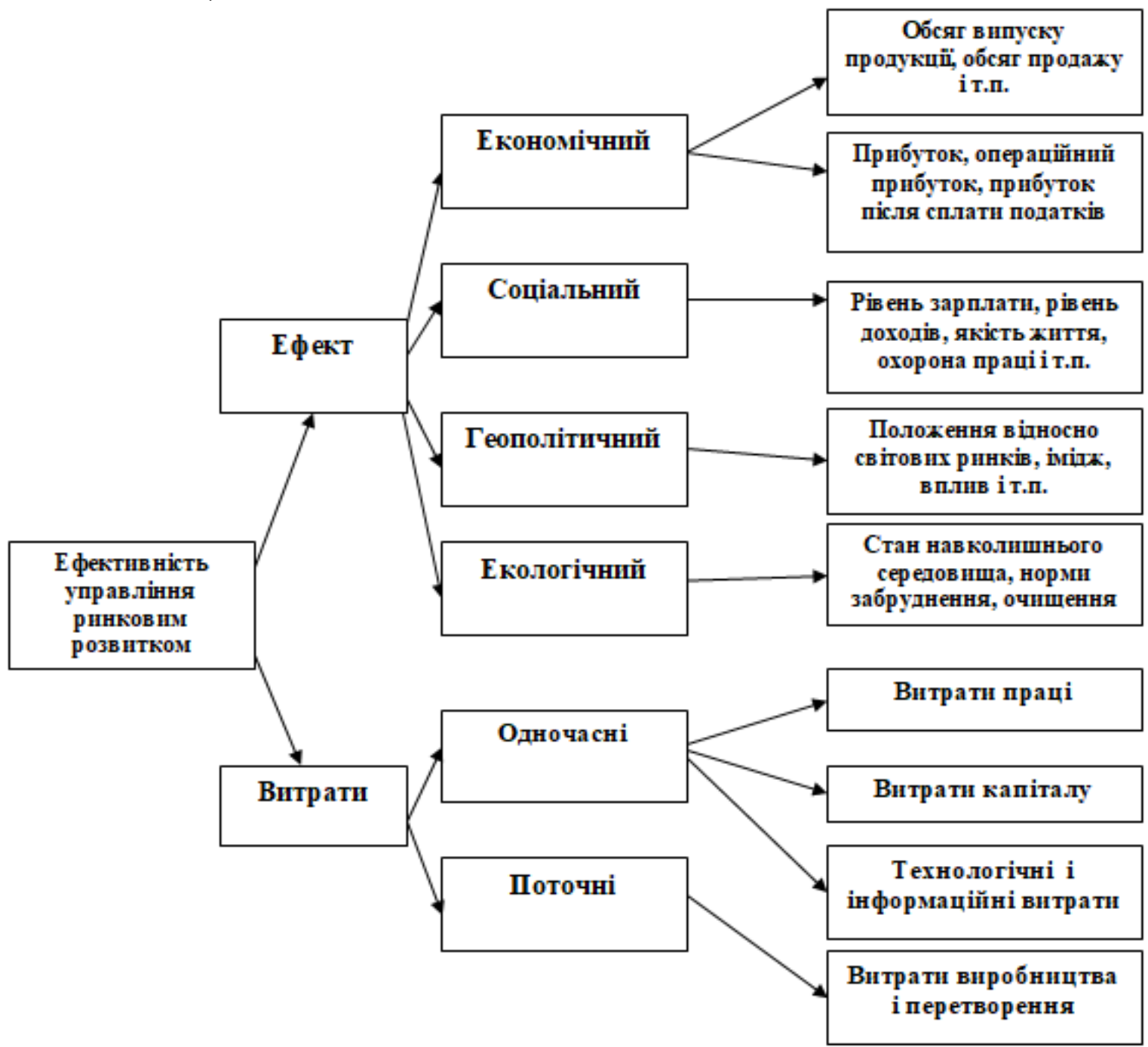

Рис. 1. Елементи, що формують ефективність управління ринковим розвитком 
Крім того, загальна стратегія довгострокового ефективного розвитку повинна охоплювати й такі напрямки розвитку, як:

- розширення попиту та пропозиції вітчизняних промислових товарів на внутрішньому ринку шляхом підвищення збалансованості виробництва, створення сприятливих умов для ведення бізнесу на основі відповідного податкового, грошового, валютного й митного регулювання;

- впровадження технічних i екологічних стандартів міжнародного рівня, зокрема ISO;

- диверсифікованість товарної структури виробництва відповідно до потреб ринку;

- надання промисловим підприємствам можливості самостійно будувати свою господарську діяльність і прагнути до виробництва продукції 3 порівняно високим рівнем доданої вартості з метою поглиблення на своїх ринкових сегментах, адаптуючись при цьому до ринкових трансформацій, визначених державними пріоритетами розвитку.

Варто враховувати також і те, що за цих умов підвищуються вимоги до визначення пріоритетів державної підтримки концептів ефективного довгострокового розвитку ринкового середовища та його екологічної складової.

Технократичні оцінки, що донедавна були ведучими у визначенні пріоритетів, уже не можуть вважатися достатніми [2], оскільки докорінно змінилася концепція до вимог суспільного розвитку та забезпечення його ефективності.

Для оцінки ефективності процесу розвитку ринку ЕЧТ пропонується використовувати модель, що враховує зв'язок i взаємний вплив мікроекономічної поведінки і макроекономічних параметрів.

Для побудови такої моделі будемо вважати, що будь-які випадкові впливи на систему відсутні й обмежимо фактори впливу чисто економічними аспектами, абстрагуючись від інших складових ефективного розвитку ринку ЕЧТ.

Припустимо, що система складається $3 \mathrm{n}$ компонентів (підприємців, включаючи підприємства й домогосподарства). Економічна поведінка кожного підприємця характеризується т-мірним вектором хі $=(x 1 \mathrm{i}, \ldots, \mathrm{xmi}),(\mathrm{i}=1, \ldots, \mathrm{n})$.

Перемінні хіj представляють реальне виробництво підприємця i. $\mathrm{C}$ q макроскопічних перемінних $\mathrm{yk},(\mathrm{k}=1, \ldots, \mathrm{yq})$, що представляють ціни, заробітну плату, ставку відсотка і т. ін. Перемінні в $=[(\mathrm{y} 1, \ldots$, yq $)]$ i хі - залежать від часу.

Розглянемо спочатку динаміку мікроскопічних перемінних. Передбачається, що на кожен момент часу кожен підприємець має ідеально повну інформацію про макроскопічні параметри.

Передбачається також, що кожен учасник ринку приймає рішення про виробництво на базі поточного виробництва й значень макроскопічних перемінних. «Прямі взаємодії» між підприємцями при цьому не враховуються. Динамічна поведінка і-ого підприємця пропонується в загальному випадку описуватися наступними рівняннями:

$$
\mathrm{dxij} / \mathrm{dt}=\operatorname{sfij}(\mathrm{xi}, \mathrm{yi}),
$$


де параметр $\mathrm{s}$ представляє швидкість установлення мікроскопічних перемінних. Різні підходи до мікроекономіки мають різні точки зору на те, як визначати конкретні функціональні форми функції f i j.

Динаміку макроскопічних перемінних у загальному випадку передбачається описувати рівняннями:

$$
\mathrm{dyk} / \mathrm{dt}=\mathrm{gk}(\mathrm{x} 1, \ldots, \mathrm{xn}, \mathrm{y})
$$

де функції gk вважаються безупинно диференційованими.

Динаміка всієї системи описується рівняннями (1) i (2). Неважко побачити, що деякі модифікації процесів, запропоновані в рівноважному підході, можна розглядати як окремі випадки загальної системи. Наприклад, якщо припустити, що s досить велика, i yk - це ціна i-ого товару, то за певних умов система може бути зведена до наступного:

$$
\begin{aligned}
& \operatorname{fij}(x i, y)=0 \\
& \text { dyk } / d t=g k(x 1, \ldots, x n, y) \ldots
\end{aligned}
$$

Таким чином, динамічна система містить тільки рух цін. Варто помітити, що в загальному випадку рівноважний обмін виникає, тільки коли ціни досягають рівноваги. Однак у ринковій економіці прийнята «адаптивна» точка зору, тобто такий обмін може виникнути, навіть коли ціни не зрівноважилися.

Розмірність повної системи звичайно, дуже висока. Оскільки система потенційно нестабільна, відповідно, можна твердити, що вона може виявляти дуже складну поведінку.

Однак, застосовуючи аналітичні методи, можна звести цю багатомірну проблему до відносно простої, що дає можливість зрозуміти і кількісно оцінити деякі властивості динамічних систем, до яких безумовно, відноситься процес довгострокового розвитку ринку ЕЧТ.

Домінуючою парадигмою нинішнього етапу економічного розвитку України виступає орієнтація управління (на різних його рівнях) на забезпечення стабільності положення й формування компонентів сталого розвитку.

Оцінка економічної ефективності управління розвитком вітчизняного ринку ЕЧТ $\epsilon$ важливим елементом самого процесу розвитку, здатним вплинути на його результативність.

Управління розвитком повинне бути орієнтоване на досягнення таких цілей, що у майбутньому забезпечать як безпосередньо товаровиробнику так й державі в цілому конкурентні переваги як на внутрішньому, так i, особливо, на зовнішньому ринках.

Цей процес пов’язаний із впровадженням нових технологій з обліком, змін що відбулися й очікуваних змін з відповідною ефективністю, із упровадженням нової техніки, що забезпечує випуск продукції, яка вимагається ринком із закріпленням і розширенням позицій підприємства не тільки на ринках України і країн СНД, але і далекого зарубіжжя, зі створенням нових робочих місць і забезпеченням світових стандартів по відношенню до стану навколишнього 
середовища, а відповідно й рівня екологічності, що відповідав би світовим вимогам.

Ефективність управління розвитком різнорівневих виробничих систем, як вказують ряд авторів $[3 ; 4 ; 6 ; 7 ; 8 ; 9]$, безпосередньо пов'язується 3 упровадженням інноваційної моделі розвитку заснованої на екологізації технікотехнологічних процесів.

Основна задача, яку необхідно вирішувати при визначенні ефективності управління розвитком ринку ЕЧТ - вибір ознак, що якнайкраще характеризують представлення про ефективність у цілому з погляду основної задачі, що стоїть перед виробничою системою.

Таким чином, ефективність управління розвитком ринку ЕЧТ пропонується розглядати з наступних точок зору - вона повинна розглядатися як ступінь ефективності виконання певних конкретних операцій, рішення локальних задач. При такому підході необхідна погодженість цілей кожної складової із загальними стратегічними задачами управління ефективним розвитком ринку в цілому.

Пропонований нами підхід відрізняється від використовуваних раніше тим, що:

- як основна мета виступає довгостроковий ефективний розвиток виробничої системи в цілому та їі екологічної складової, зокрема;

- орієнтацією на постійне підвищення ефективності функціонування кожної ланки, групи, підрозділу, що виступають єдиним комплексом, що забезпечує довгостроковий ефективний розвиток;

- припускає не одноразове рішення проблем відносно «вузьких місць» у роботі підприємства, а постійну концентрацію зусиль на розвиток на основі підвищення ефективності у всіх ланках системи управління в комплексі 3 виробничим процесом.

Особливий інтерес до оцінки ефективності управління розвитком визначений тією роллю, що відіграє дана система в якості основної рушійної сили науково-технічного прогресу, що $є$ вирішальною ланкою в сучасних умовах конкурентної боротьби.

Низька ефективність управлінських дій - це перший і досить важливий сигнал можливої майбутньої кризи. Тому при оцінці ефективності управління довгостроковим розвитком дуже корисні наступні показники ефективності, що на більш ранній стадії дозволяють оцінити можливі труднощі наперед, обумовлені недостатньою увагою до питань розвитку: час, який необхідний, щоб продукт і послуга вийшли на ринок, зокрема це можливе при виході на ринок екологічно чистих продуктів 3 інноваційним товаром що відрізняється екологічною чистотою $[1 ; 3 ; 7 ; 8]$.

У цих умовах розвиток виробництва реалізується в першу чергу не в кількості вироблених товарів, а в їхньому якісному удосконалюванні, що досягається шляхом частої зміни асортименту виробленої продукції, зокрема екологічно чистої.

Висновки і перспективи подальших досліджень. Дослідження показало, що на сьогодні в Україні сформоване теоретико-методологічне підгрунтя для подальшого розвинення ринку екологічно чистих товарів й ефективного управління таким розвитком в довгостроковій перспективі. 
Традиційні методи визначення ефективності ринкового розвитку, у першу чергу, кількості вироблених продуктів, що відображають збільшення послуг, не дають можливості повною мірою оцінити фактичні та передбачувані зміни за ланцюгом наростаючого ефекту від використання існуючих технологій i застосування нових продуктів, націлених, насамперед, на економію ресурсів, екологізацію і індивідуалізацію як виробництва, так і споживання.

Ефективність управління розвитком ринку екологічно чистих товарів виражається через рівень досягнення економічних і соціальних цілей розвитку і являє собою суму економічного, науково-технічного, соціального й екологічного ефектів. Економічна ефективність управління розвитком ринку ЕЧТ безпосередньо пов'язана із упровадженням високотехнологічних виробництв, але все-таки це не є єдиним джерелом росту. Вона розглядається як здатність системи управління в процесі функціонування продукувати ефективність через ефективність складових іiі елементів на підставі побудови багатофакторних та багатовекторних моделей розвитку.

Подальші дослідження слід сконцентрувати на апробації отриманих теоретико-методологічних засад ефективного розвитку ринку ЕЧТ на підставі конкретного статистичного матеріалу, щодо оцінки ефективності розвитку окремих промислово розвинених регіонів 3 високим рівнем впровадження інновацій 3 проєктуванням отриманих результатів на економічну систему України в цілому.

Лimepamypa:

1. Должанський І. 3., Бєлякова О. В. Організація процесу формування та розвитку ринку екологічно чистих товарів: монографія. Донецьк: СПД Купріянов В. С., 2009. 230 с.

2. Зотов В. В., Пресняков В.Ф. Фирма как экономическое явление и институт общества. Экономика и математические методы. 2005. Т. 31. C. $36-37$.

3. Ілляшенко С. М., Прокопенко О. В. Формування ринку екологічних інновацій: економічні основи управління: монографія. Суми: ВТД «Університетська книга», 2002. 250 с.

4. Концепція державної промислової політики України. / За ред. М. Г. Чумаченка, О. І. Амоші. Донецьк: ІЕП НАН України, 2005. 328 с.

5. Гришин И. Концепция устойчивого развития в контексте глобализации. Мировая экономика и международные отношения. 2007. № 6. С. 66-79.

6. Марова С. Ф., Токарева В. І., Солоха Д. В. Дослідження умов адаптації концептів державного управління розвитком регіональних інноваційних структур розвинених країн в Україні. Менеджер. Вісник Донецького державного університету управління. Серія «Державне управління», 1(86). Маріуполь: ДонДУУ, 2020. С. 33-60.

7. Садеков А. А. Механизм эколого-экономического управления предприятием: монография. Харьков: Издательский Дом «ИНЖЭК», 2004. 224 с.

8. Солоха Д., Іванова В., Бєлякова О., Молярова Л. Теоретикометодологічні аспекти формування екологічної політики в системі національної 
економіки на інноваційних засадах розвитку: монографія / за наук. редакцією д-ра екон. наук, проф. Д. Солохи. Київ: КНУКіМ, 2018. 136 с.

9. Штулер І. Ю. Стабілізація економіки України: інноваційний підхід. Економічний аналіз: зб. наук. праць. Тернопільський національний економічний університет. Тернопіль: Видавничо-поліграфічний центр Тернопільського національного економічного університету «Економічна думка», 2016. Том 23. № 1. C. 106-110.

\section{References:}

1. Dolzhansjkyj I. Z., Bjeljakova O. V. Orghanizacija procesu formuvannja ta rozvytku rynku ekologhichno chystykh tovariv: monoghrafija. Donecjk: SPD Kuprijanov V. S., 2009. 230 s.

2. Zotov V. V., Presnyakov V. F. Firma kak ekonomicheskoe yavlenie i institut obshchestva. Ekonomika i matematicheskie metody. 2005. T. 31. S. 36-37.

3. Illjashenko S. M., Prokopenko O. V. Formuvannja rynku ekologhichnykh innovacij: ekonomichni osnovy upravlinnja: monoghrafija. Sumy: VTD «Universytetsjka knygha», 2002. $250 \mathrm{~s}$.

4. Koncepcija derzhavnoji promyslovoji polityky Ukrajiny. / Za red. M. Gh. Chumachenka, O. I. Amoshi. Donecjk: IEP NAN Ukrajiny, 2005. 328 s.

5. Ghryshyn Y. Koncepcyja ustojchyvogho razvytyja v kontekste ghlobalyzacyy. Myrovaja эkonomyka y mezhdunarodnыe otnoshenyja. 2007. \# 6 . S. 66-79.

6. Marova S. F., Tokareva V. I., Solokha D. V. Doslidzhennja umov adaptaciji konceptiv derzhavnogho upravlinnja rozvytkom reghionaljnykh innovacijnykh struktur rozvynenykh krajin v Ukrajini. Menedzher. Visnyk Donecjkogho derzhavnogho universytetu upravlinnja. Serija «Derzhavne upravlinnja», 1(86). Mariupolj: DonDUU, 2020. S. 33-60.

7. Sadekov A. A. Mekhanizm ekologo-ekonomicheskogo upravleniya predpriyatiem: monografiya. Khar'kov: Izdatel'skiy Dom «INZhEK», 2004. 224 s.

8. Solokha D., Ivanova V., Bjeljakova O., Moljarova L. Teoretykometodologhichni aspekty formuvannja ekologhichnoji polityky v systemi nacionaljnoji ekonomiky na innovacijnykh zasadakh rozvytku: monoghrafija / za nauk. redakcijeju d-ra ekon. nauk, prof. D. Solokhy. Kyjiv: KNUKiM, 2018. 136 s.

9. Shtuler I. Ju. Stabilizacija ekonomiky Ukrajiny: innovacijnyj pidkhid. Ekonomichnyj analiz: zb. nauk. pracj. Ternopiljsjkyj nacionaljnyj ekonomichnyj universytet. Ternopilj: Vydavnycho-polighrafichnyj centr Ternopiljsjkogho nacionaljnogho ekonomichnogho universytetu «Ekonomichna dumka», 2016. Tom 23. \# 1. S. 106-110.

The work is devoted to a very important problem of modernity - the definition of theoretical and methodological concepts of effective management of the market for environmentally friendly goods in Ukraine.

According to the implementation of the principles of the Concept of Sustainable Development, very important in modern business conditions is the greening of production to produce the maximum number of environmentally friendly goods, with 
environmental friendliness at all stages of production - raw material extraction to sell finished products.

It is proved that the global criterion of effective management of the market environment in general and the market of environmentally friendly goods, as its important component is the sustainable development of the national economy in the strategic perspective with all the full performance of its functions.

To assess the effectiveness of the process of developing the market for environmentally friendly goods, it is proposed to use a model that takes into account the relationship and mutual influence of microeconomic behavior and macroeconomic parameters.

To build such a model, we will assume that any accidental effects on the system are absent and limit the factors of influence to purely economic aspects, abstracting from other components of effective market development of environmentally friendly goods.

However, using analytical methods, we can reduce this multidimensional problem to a relatively simple one, which makes it possible to understand and quantify some properties of dynamic systems, which certainly include the process of long-term development of the market for environmentally friendly goods.

The dominant paradigm of the current stage of economic development of Ukraine is the orientation of management (at its various levels) to ensure the stability of the situation and the formation of components of sustainable development.

Assessing the economic efficiency of managing the development of the domestic market of environmentally friendly goods is an important element of the development process itself, which can affect its effectiveness.

Development management should be focused on achieving such goals that in the future will provide both directly to the producer and the state as a whole competitive advantages in both domestic and, especially, foreign markets.

The main task to be solved in determining the effectiveness of managing the development of the market for environmentally friendly goods - the choice of features that best characterize the idea of efficiency in general in terms of the main task facing the production system.

Thus, the effectiveness of managing the development of the market of environmentally friendly goods is proposed to be considered from the following points of view - it should be considered as the degree of efficiency of certain specific operations, solving local problems. This approach requires consistency of the objectives of each component with the overall strategic objectives of managing the effective development of the market as a whole. 